\title{
The white-seared landscape: Walkabout as iconic Australian counterculture
}

\author{
Jack McDonald
}

Nicolas Roeg's Walkabout, a 1971 Australian New Wave film, has ignited and continues to ignite a deep desire in its audience to ruminate and engage with Aboriginal political discourse. This seminal work emerged out of social unrest for the injustices performed on Aborigines at the time, and made a definitive mark on how Australian's think about race relations, intercultural understanding, and the place of empathy and thoughtfulness in a shifting and vibrant political landscape. Through the film, Roeg highlights the importance of sacred land and cultural heritage to the Aboriginal people, and the obligation white Australia has to respect and appreciate such a deep and fundamental component of the continent's history.

An indelible element of Walkabout is the earth itself, framing hardship and possibility through differing character motivations. The awareness and thematic importance Roeg shows of this directly highlights Australia's colonial history; European colonists were not concerned with acquiring trade or labour, but of expropriating Aboriginal land (Morris 1989). Keeping this in mind, the 1960s saw a great rise in awareness and reflection on race and cultural relations in Australia, shown by: increased mobilisation for desegregation of public spaces, protests and conversations interrogating land rights and native title for Aborigines, and the 1967 Australian referendum resulting in the constitutional recognition of Aboriginal people (Goodall 1995). Walkabout's release in the wake of this climate explains and complicates certain social and political components, both explicit and implicit, within the film. Beyond the substance of the work, however, is a clear desire to examine and reflect on the state of Australian society at this time, and consider where the nation should proceed. Walkabout therefore defines itself as 'an indigenous presence... and a force with which others must reckon' (Ginsburg \& Myers p. 29).

The film focuses on three protagonists, Girl and White Boy, who are driven into the Australian outback after their father shoots a gun at them in a hallucinatory fervour. The father dies, and slowly the pair teeter on the verge of death. Black Boy appears, keeping them alive as they slowly drift back towards Roeg's symbolic "civilisation". What stands out, even in this simple synopsis, is Roeg's deliberate distillation of each "character" into their gender and race, featuring Jenny Agutter as "Girl", David Gulpilil as "Black Boy", and Luc Roeg as "White Boy". This could be attributed to the lackadaisical dialogue between characters, however considering the importance of identity to the 
film the superficial labelling speaks more broadly about the language of diversity and racism. Hickling-Hudson has noted the way that race defamation towards the Aborigines emerges explicitly is via 'derogatory stereotypes and abusive and contemptuous language' (1990, p. 263); Roeg appears to utilise this restrictive and inflammatory language, however simultaneously subverts it by distilling the white populous of the film in the same way and stereotyping their characteristics. Hickling-Hudson goes on to call out Walkabout for being too narratively simplified, ending in a grand romanticism of the exotic and foreign in an exclusive, not inclusive manner; I believe this is agreeable to the extent of poor plotting and characterisation, however linguistically and symbolically Roeg interrogates racist comments conceptually, rather than in a utilitarian and slanderous way.

The film opens with a waterfall of "modern Australian" imagery: office workers and white citizens roaming Sydney's CBD, skyscrapers and architecture overwhelm the senses. Roeg distinguishes and defines these locales through structure, or the lack thereof, highlighting an interest in the "sparse" Aboriginal landscape, as seen through the eyes of Girl and White Boy. Unfolding throughout the story is the juxtaposition of active and despairing "whiteness", with passive and adept Aboriginality. The protagonists work together, and in conjunction, towards a goal of "returning home". Roeg utilises tropes of the native and the damsel in distress, and places them within this context to illuminate expectation and reality between cultures.

The "walkabout" acts a lynchpin for this argument: Taylor posits that the "walkabout" [was] adopted colloquially to denote the seemingly unexplainable and unplanned nature of trips' some Aborigines take through the bush (2014 p. 242). What the film declares is that this is a heritage ritual, that there is undoubtedly purpose and reason to Aboriginal culture, and a uniquely "white" disinterest in understanding is the root of incomprehension. Walkabout emphasises this incomprehension through its protagonists, and takes the audience on a journey to a history that permeates all land in the nation.

Fundamentally woven throughout the plot, characters, imagery and themes is a deep desire for understanding and communication. This appears on screen literally in the form of artwork, storytelling, and the observation of one another's physical bodies. It also translates more unconsciously through the performance of Gulpilil's native language, as well as cinematic vigilance of native tradition and culture such as watching Gulpilil hunting and utilising the land to help the siblings. Nicolas Roeg plays poetically on these presentations of art and tradition as a form of absorption to subtly identify a type of "modern colonialism". When trying to justify an ownership such as native title, around the time this film was released there was an inability to 'satisfactorily demonstrate what was called "traditional attachment to the land" which meant that indigenous custodians were "doubly dispossessed by their apparent "lack of Aboriginal culture" (Ginsburg \& Myers 2006, p. 33) according to technicality. Walkabout emphasises this as ignorant and discriminative practice, taking the time to humanise and communicate Gulipilil's character and motivations for an audience that may otherwise feel they have no obligation to learn.

In the final act of the film, a haunting montage echoes throughout and beyond the end credits, utilising the recurrent theme of "witnessing" to signify and define Roeg's political filmic determination. A group of white scientists hunt animals in an all-terrain vehicle, almost running 
over Black Boy in the process. This symbolic scene, of "civilisation" attempting to crush the Aborigine, leads into the montage of a buffalo being shot and exsanguinated. Time reverses, the animals freeze, White Boy and Black Boy simultaneously experience the death of the buffalo; the weight of colonial civilisation encroaches into their previously untouched space, the breadth of the landscape suddenly ceases to be limitless. A unity and bond between the boys pierces through cultural trepidation, political boundaries, and racial disparateness.

The director utilises participatory consciousness to help westerners understand and empathise with the indigenous population, 'upset when landscape, creatures and especially sacred sites are destroyed: the pain of the whole is felt by the people as in their own flesh' (Fletcher 1996, p.167). Roeg protests segregation and unwillingness to empathise and understand the plight of being Aborigine in what he argues is a "white society". The importance of culture and identity for Australian Indigenous people cannot be understated, and any attempt to emphasise and educate audiences about the vital nature of this history is definitely worth experiencing.

\section{References}

Fletcher, F. 1996, 'Towards a Dialogue with Traditional Aboriginal Religion', Pacifica, vol. 9, pp. 164-174. https://doi.org/10.1177/1030570x9600900204

Ginsburg, F. \& Myers, F. 2006, 'A history of Aboriginal futures', Critique of anthropology, vol. 26, no. 1, pp. 27-45. https://doi.org/10.1177/0308275x06061482

Goodall, H. 1995, 'New South Wales', in Ann McGrath (ed.), Contested ground: Australian Aborigines under the British crown, Allen \& Unwin, New South Wales, pp. 55-120.

Hickling-Hudson, A. 1990, 'White construction of black identity in Australian films about Aborigines', Literature film quarterly, vol. 18, no. 4, pp. 263-271.

Morris, B. 1989, 'Colonial domination as a process of marginalisation', in Domesticating resistance: the Dhan-Gadi Aborigines and the Australian state, Oxford, pp. 6-30.

Taylor, A. 2014, "“Walkabout tourism": is there an Indigenous tourism market in outback Australia?', Athens Journal of Tourism, vol. 1, no. 4, pp. 239-252.

(C) 2018 by the author. This article is distributed under the terms and conditions of the Creative Commons Attribution license (http://creativecommons.org/licenses/by-nd/4.0/). 